\title{
Creativity, social and political attitudes, and liking or disliking David Duke
}

\author{
RUSSELL EISENMAN \\ McNeese State University, Lake Charles, Louisiana
}

\begin{abstract}
Measures of creativity (complexity-simplicity preferences) and social and political attitudes were obtained from 52 Louisiana university students about a month before the U.S. Senate election. Of interest was the reason for liking or disliking the candidate David Duke, a former leader of the Ku Klux Klan and Nazi sympathizer. The creativity measure was significantly related to liking or disliking Duke: liking Duke was associated with preference for simplicity, which suggests low creativity. Although students showed preferences for some of the social and political variables, these variables were not related to attitude toward Duke. Finally, the simple, anonymous measurement procedures used here accurately predicted that Duke would do well in the campaign and receive more than $50 \%$ of the white vote. This is in stark contrast with the predictions of political pollsters and experts who seriously underestimated his strength.
\end{abstract}

David Duke is one of the most interesting political phenomena of recent times. A member of the Louisiana House of Representatives, he is also a former head of the $\mathrm{Ku}$ Klux Klan and a former Nazi party sympathizer. He ran a strong race for the U.S. Senate seat of Democratic incumbent J. Bennett Johnston. Even though repudiated by the national Republican party, Duke ran as a Republican and confounded pollsters and political experts by receiving $44 \%$ of the vote in a losing effort (Freemantle, 1990; "'Roemer, Edwards,"' 1991). Pollsters and political analysts had predicted that Duke would be lucky to get even $30 \%$ of the vote (Freemantle, 1990). Election results showed that Duke received between $55 \%$ and $60 \%$ of the white vote in Louisiana, and a stronger than expected percentage of the black vote. Part of his effectiveness is that he denies current attachment to the Ku Klux Klan or the Nazis and puts his past involvement down to youthful indiscretion. The present study was conducted with university students in Louisiana about a month before the Senate election, in order to see what variables might account for students' liking or disliking of David Duke.

Duke's appeal seems to involve racist, populist, and disguised racist appeals. Those who feel positive about his white power approach out of hatred for blacks and other minorities can see, in his past, behavior consistent with their views. As a populist, Duke, a handsome and youthful person, appears to be different from the regular politician. He comes across as a man of the people-especially white people who have been threatened by the poor economic conditions in the state. Finally, one who holds ra-

\footnotetext{
Grateful appreciation is expressed to Keith Whitfield for his excellent statistical assistance and advice. Address requests for reprints to Russell Eisenman, Department of Psychology, McNeese State University, Lake Charles, LA 70609-1895.
}

cist views but does not want to admit them either to oneself or others can claim to be for David Duke in spite of, not because of, his past Ku Klux Klan and Nazi ties. In some ways Duke's appeal seems similar to that of the authoritarian personality (Adorno, Frenkel-Brunswik, Levinson, \& Sanford, 1950), for he emphasizes sentiments against marginalized groups such as blacks, people on welfare, and criminals. For example, in his campaign Duke repeatedly spoke against affirmative action, misuse of welfare, and gun control. He presents himself as an advocate of white people, and he is the head of a group he founded called National Association for the Advancement of White People, an obvious takeoff on the name of the National Association for the Advancement of Colored People. Given all of the above, it seems that Duke would appeal to people low in creativity, for creative people tend to look at issues in a more complex way and should be somewhat immune to simplistic or authoritarianlike appeals (Barron, 1990; Eisenman, 1991; Runco, in press-a, in press-b).

The present study involved assessing student creativity with a measure of preference for complexity-simplicity in polygons, which has been shown in past research to be related to creativity (Eisenman, 1968a, 1968b, 1990, 1991; Eisenman, Borod, \& Grossman, 1972; Eisenman \& Schussel, 1970; Victor, Grossman, \& Eisenman, 1973). Eisenman et al. (1972) showed that preference for complexity in the polygons was associated with the complexity score on the Barron-Welsh Art Scale. Barron (1990) reports extensive research showing how the complexity score is consistent with creativity. Also, I have found, in unpublished research, that music students who won national awards for their musical ability and were rated by their instructor as creative were higher in polygon complexity preference than were students who did not win national awards and were rated as noncreative by their instructor. 
Since Duke's appeal seems to be an indirect or disguised racism for some, it was thought wise to use indirect measures to try to understand the source of his appeal. Thus, among the measures utilized were like-dislike ratings on social and political issues that do not directly ask about racism or rejection of marginalized groups, but that might indirectly tap such feelings. For example, it is possible that Duke followers would dislike the poor, the homeless, and rap singers. While a question about liking or disliking the poor is a fairly direct means of assessment, a question about the homeless is less obvious in its intent, given the generally bad publicity homeless people tend to get in the media, and a question about rap singers, most of whom are black, is a very indirect assessment of racist attitudes. A rejection of rap singers per se could simply reflect an aesthetic preference, but if it occurs in the context of a disliking of the poor, the homeless, and a liking of David Duke, it might be part of a syndrome of authoritarian-type attitudes. Further questions included such topics as liking or disliking the police, on the assumption that Duke supporters would also like the representatives of law and order.

\section{METHOD}

\section{Subjects}

The subjects were 52 college students in a Louisiana university. They were tested during their introduction to psychology class as part of a classroom project to show how research is done. Later, the instructor went over the results with the class. The students were almost all freshmen or sophomores, and they were mostly not psychology majors. Five, at the most, were psychology majors. Forty-three students listed themselves as white on the questionnaire, 6 as black, and 3 did not list their race. There were 37 females and 15 males.

\section{Procedure}

The instructor passed out a two-page document. The first page consisted of items designed for this research. They included questions about the sex, race, birth order, and political preference of the student (with "liberal," " conservative," and "other" listed after political preference), and 22 items that the students were asked to rate by circling the word "like" or "dislike," which appeared after each item to be rated. The items included a wide array of topics of social or political interest, such as David Duke, George Bush, police, fraternity members, sorority members, happy people, sad people, abortion supporters, abortion foes, rap singers, Madonna, and so forth. When students asked questions such as "What if you can't decide?" they were told to try to choose "like" or "dislike," but that it was all right to leave it blank or circle the space in between if they truly could not come up with a "like" or "dislike" response.

On the second page were the 12 polygons used extensively by the author in previous research (e.g., Eisenman, 1990, 1991). Nine polygons were asymmetrical forms previously used by Vanderplas and Garvin (1959) and had originally been constructed by randomly connecting points on a $100 \times 100$ grid (Attneave \& Arnoult, 1956). The three symmetrical shapes were taken from Birkhoff (1933). The nine asymmetrical shapes consisted of three each with 4,12 , or 24 points, where points or turns (both have the same meaning here) define complexity. Inward points count just as do outward points, which stick out. The symmetrical polygons had 4,8 , or 10 points. A symmetrical polygon with 4 points is actually less complex than an asymmetrical one with 4 points, since a person can predict half of a symmetrical one by looking at the other half. The students were told to circle their three most preferred choices. A complexity score was then obtained by adding up the number of points on the circled polygons. On the basis of previous research, it was determined that a score of $\mathbf{4 0}$ was a reasonable cut-off point for defining complexity. To get a score of 40 , one must choose at least one of the highest complexity polygons, a 24-point one. Also, one must choose at least a middle-complexity 12-point polygon if no other 24-point polygons are chosen. Then, one could also choose one 4-point polygon to achieve a 40-point score. This is actually a somewhat liberal definition of complexity preference, but it ensures that people who score on the simplicity side are truly preferring simplicity.

\section{RESULTS}

\section{Complexity-Simplicity Preferences}

There were 28 students in the sample who indicated like for David Duke and 20 who indicated dislike. Four students did not indicate either like or dislike, either because they did not answer the question or because they checked off the middle between the "like" and "dislike" answers. There were major complexity-simplicity preference differences between the students who indicated like versus dislike of David Duke. Almost all of the David Duke likers preferred simplicity (24 out of the 28 failed to get a score of $\mathbf{4 0}$ points on their three most preferred polygons, which was the definition of complexity chosen, on the basis of past research), while the 20 students who indicated dislike of David Duke were slightly toward the complexity side [11 preferred complexity, 9 preferred simplicity; $\left.\chi^{2}(1)=7.21, p=.007\right]$, Thus, liking David Duke is associated with liking simplicity in polygons, the kind of polygons that noncreative people tend to prefer.

\section{Social and Political Attitudes}

There were many significant findings regarding the social and political variables, in terms of the preferences of these college students. However, not all were in the direction one might expect, and some that one might have expected to be significant were not. For example, there was no difference in political preference: 23 students rated themselves as liberals, 22 as conservatives, and 7 as neither. Given the recent negative publicity that liberals have received and the success of presidents Ronald Reagan and George Bush in fostering political conservatism, these results may be surprising, especially with respect to Southern students. Also, the students did not display a clear ideology in their choices. Out of those who reported like or dislike regarding the police, 32 liked the police and 16 disliked the police $\left[\chi^{2}(1)=5.33, p<.05\right]$; 42 out of 49 reporting students liked the poor $\left[\chi^{2}(1)=\right.$ $24.18, p<.001$ ]; and 33 out of 47 reporting students disliked abortion supporters $\left[\chi^{2}(1)=7.68, p<.01\right]$. Additional significant findings will be reported elsewhere; they are not of central concern to the issues studied in the present research.

Of central interest is the relationship of the social and political attitudes to liking or disliking David Duke. None of the students' social or political attitudes were related to like or dislike of Duke, even though these attitudes often suggested strong preferences. Only the creativity measure showed a significant Duke effect, as reported above.

\section{Support for Duke}

As mentioned in the beginning of this article, pollsters and political experts predicted that Duke would be for- 
tunate to receive as much as $30 \%$ of the vote in his U.S. Senate attempt. However, he received $44 \%$ of the vote and a slight majority of the white vote (Freemantle, 1990). Since this study was done in Louisiana approximately a month before the election, the question arises, did the present results predict Duke's vote better? The answer is clearly "yes." A slight majority of the class said they liked David Duke, which is consistent with his obtaining a slight majority of the white vote in Louisiana. Thus, the simple procedures used in this research predicted the election outcome better than professional pollsters and political experts did. Also, of the 6 blacks who identified themselves by race ( 3 students did not answer the race question) 2 said they liked Duke and 4 said they disliked him. Although caution must be exercised due to the very small numbers here, these results are again consistent with the election results and are against the common sense of many; not all blacks dislike David Duke.

\section{DISCUSSION}

The major findings of the present study are that liking for David Duke, former Ku Klux Klan leader and Nazi sympathizer, is associated with preference for simplicity in polygons, which suggests low creativity. Also, the simple procedures in the present study predicted the results of Duke's run for the Senate seat better than did the predictions of professional pollsters and political experts. Pollsters may be hampered by having to use a more personal approach; they either ask persons polled to identify themselves or they talk to them on the telephone and thus have potential access to their names. In the present study, the questions were answered anonymously. People may be more willing to admit support for a controversial candidate with a flawed background if they do not have to identify themselves. Perhaps, when people must answer another person face to face or via telephone, they are inhibited from admitting things they really feel. If this speculation is correct, anonymous questionnaires may often be more successful in obtaining correct findings than political polls or techniques that deprive the subject of anonymity.

The fact that Duke's supporters in the college classroom liked simplicity is consistent with what was expected. A candidate with a racist past and a possible racist campaign should appeal most to those with a simple outlook and least to those who are creative and tend to look at things more complexly (Barron, 1990; Eisenman, 1991).

It is interesting that the personality variable, creativity, distinguished those who liked or disliked David Duke, while the social and political variables did not. Since Duke is a politician running for political office, one might think that the social and political issues would have more relevance. And they did show preferences among the students, so the method of assessment is not without merit. However, Duke is an unusual type of politician, which is part of his appeal. An Associate Press story said that many who turn to Duke are alienated, white, middle class people who feel the Democratic Party has let them down ("Many turning," 1991). Thus, Duke has pulled off the trick of appearing to be antipolitical while running for political office. He may thus appeal to those who are apolitical and see him as a charismatic person rather than a politician. Many college students may be essentially apolitical. For them, a personality variable would have more predictive power than would political and social variables.

Part of Duke's appeal would seem to be his denial of his past Ku Klux Klan and Nazi activities by claiming they were youthful indiscretions. However, an Associate Press story says that Duke was selling pro-Nazi literature from his legislative office as recently as 1989 ("Newspaper ad," 1991). This would seem inconsistent with his claimed rejection of Nazi or Ku Klux Klan ties. But many have believed him or wish to believe him, so it is a clever strategy to deny a stigmatizing past (Eisenman, 1991; Goffman, 1963; Jones et al., 1984). In the case of Duke, this "stigma" is a double-edged sword. For some his past Ku Klux Klan and Nazi involvements would make him undesirable, at least in terms of getting their vote. But, for other, more prejudiced individuals, these past memberships or sympathies are a plus, showing that Duke thinks as they do. People may forget how violent these groups are and think of them as representing a pro-white position, as against the perceived influence of blacks and other minorities. If this reasoning seems farfetched, consider that Sirgo and Eisenman (1990) found that conservatives believe that the federal government favors minorities, such as blacks or the poor. A recent telephone survey by a polling organization, the Garin-Hart Strategic Research Group, found that over 50\% of Duke's voters liked him for pro-white or racially motivated reasons: $24 \%$ liked him because he was "pro-white," another $24 \%$ liked him because of his promise to clean up the "welfare mess," and 7\% said that they liked him for his opposition to affirmative action ("Many turning," 1991).

As of this writing, Duke is now a candidate for the Governorship of the state of Louisiana. His support base seems to be growing from his original base of people who are white, under 35 years old, with only a high school education, to include college-educated, affluent people ("'Roemer, Edwards," 1991). What is striking is that despite his past leadership of the Ku Klux Klan and his endorsement and support for Nazis, Duke receives support from people with college education. Instead of seeing him as having been a member of violent, basically antiAmerican organizations, people apparently see him as someone who will clean up the mess that the traditional politicians have made. Thus, distrust of government, which seems very high (Sirgo \& Eisenman, 1990) works to Duke's advantage. And it may be that many people believe him when he says his past ties to Nazis or the Ku Klux Klan do not represent his present beliefs.

\section{REFERENCES}

Adorno, T. W., Frenkel-Brunswik, E., Levinson, D. J., \& SANFORD, R. N. (1950). The authoritarian personality. New York: Harper \& Row.

Attneave, F., \& Arnoult, M. D. (1956). Methodological considerations in the quantitative study of shape and pattern perception. Psychological Bulletin, 53, 452-471.

BARRON, F. (1990). Creativity and psychological health: Origins of personal vitality and creative freedom. Buffalo, NY: Creative Education Foundation.

BirkhofF, G. D. (1933). Aesthetic measure. Cambridge, MA: Harvard University Press.

EISENMAN, R. (1968a). Complexity-simplicity and reaction to threatening information. Journal of Consulting \& Clinical Psychology, 32, 638-641.

Eisenman, R. (1968b). Personality and demography in complexitysimplicity. Journal of Consulting \& Clinical Psychology, 32, 140-143.

EISENMAN, R. (1990). Creativity, preference for complexity, and physical and mental illness. Creativity Research Journal, 3, 233-238.

Eisenman, R. (1991). From crime to creativity: Psychological and social factors in deviance. Dubuque, IA: Kendall/Hunt.

Eisenman, R., Borod, J., \& Gossman, J. C. (1972). Sex differences in the interrelationships of authoritarianism, anxiety, creative attitudes, preference for complex polygons, and the Barron-Welsh Art Scale. Journal of Clinical Psychology, 28, 549-550.

Eisenman, R., \& Schussel, N. R. (1970). Creativity, birth order, and preference for symmetry. Journal of Consulting \& Clinical Psychology, 34, 275-280.

Freemantle, T. (1990, October 8). Strong finish indicates Duke is future force. Houston Chronicle, pp. 1A, 6A.

Goffman, E. (1963). Stigma. Englewood Cliffs, NJ: Prentice-Hall. Jones, E. E., Farina, A., Hastorf, A. H., Markus, H., Miller, D. T., \& ScotT, R. A. (1984). Social stigma: The psychology of marked relationships. New York: W. H. Freeman.

Many turning to Duke out of frustration, pollster says. (1991, March 27). Lake Charles American Press, p. 10.

Newspaper ad labels Duke "an antichrist." (1991, March 30). Lake Charles American Press, p. 3. 
Roemer, Edwards leading, but Duke looks like wild card. (1991, March 27). Lake Charles American Press, p. 10.

Runco, M. A. (Ed.) (in press-a). Divergent thinking. Norwood, NJ: Ablex.

Runco, M. A. (Ed.) (in press-b). Problem finding, problem solving, and creativity. Norwood, $\mathrm{NJ}$ : Ablex.

Sirgo, H. B., Eisenman, R. (1990). Perceptions of governmental fairness by liberals and conservatives. Psychological Reports, 67, 1331-1334.
Vanderplas, J. M., \& Garvin, E. A. (1959). The association value of random shapes. Journal of Experimental Psychology, 57, 147-154.

Victor, H. R., Grossman, J. C., \&isenman, R. (1973). Openness to experience and marijuana use in high school students. Journal of Consulting \& Clinical Psychology, 41, 78-85.

(Manuscript received June 15, 1991.) 